\title{
RADIOACTIVE ATMOSPHERIC DISCHARGES OF THE EUROPEAN AND RUSSIAN NUCLEAR POWER PLANTS
}

\section{Michael Zhukovsky1,2*, Aleksey Vasilyev', Aleksey Ekidinn,2, Maksim Vasyanovich',2, Maria Pyshkina², Maksim Semenov3, Ekaterina Murashova3, Ivan Kapustin4}

\author{
${ }^{1}$ Institute of Industrial Ecology UB RAS, Ekaterinburg, Russia \\ ${ }^{2}$ Ural Federal University, Ekaterinburg, Russia \\ 3Mayak Production Association, Ozersk, Russia \\ 4Karpov Institute of Physical Chemistry, Moscow, Russia
}

\begin{abstract}
Comparison of radionuclide specific indicators in airborne discharges to atmosphere from European and Russian nuclear power plants was carried out. The performed analysis allows determining airborne discharge structure and the environmental impact of nuclear power plant with different types of reactor. Analysis of experimental data on radioactive airborne discharges from Russian nuclear power plants is carried out. The nuclear power plants with three different kinds of reactors are investigated. The performed analysis allows determining the list of radionuclides in airborne discharges, which give from 84 to $99 \%$ of radiation exposure population.
\end{abstract}

Key words: NPP, airborne discharges, radionuclides, reactor

DOI: $10.21175 /$ RadProc.2017.26

\section{INTRODUCTION}

One of the greatest achievements of the XX century is the nuclear power. Nevertheless, nuclear energy is not only an advantage, but also a potential hazard. Nuclear power plants (NPP) are source of radionuclides contamination and potential risk to humans and the environment. Identification of the main dose-forming atmospheric discharges of NPP was carried out in $[1,2]$, which showed that the level of contamination depends on the type and design of nuclear reactor. This work aims to summarize the raw data on atmospheric discharges of pressurized water reactors (PWR) and their Russian analogs known as VVER (abbreviation of Russian term "Vodo-vodyanoy energeticheskiy reactor") nuclear reactors in Europe and Russia. Interest to this generalization originated due to the fact that in Russia there are only 7 radionuclides under control (Cs-137, Cs-134, Co-58, Co-6o, Cr-51, Mn-54, I-131, control of $\mathrm{H}-3$ and $\mathrm{C}-14$ has recently begun on some NPP), while in Europe the number of controlled nuclides is up to 53 .

Both IAEA recommendations and legal acts of the Russian Federation required a necessity monitoring of atmospheric emissions in NPPs with up to 94 radionuclides [3, 4]. Russian NPPs at nominal operation do not achieve the dose quota for population due to radioactive gas and aerosol airborne discharges [5]. Nevertheless, the control of radiation parameters of technological air ventilation systems, workplaces and in the environment is needed for the planning and implementation of measures for protection of population and environment. On the other hand, nominal radiation monitoring systems are not always able to reliably determine the radionuclide concentration in NPP airborne discharges.

Aims of this research are the following:

- to compare indicators of atmospheric discharges of nuclear power plants in Russia and Europe;

- to consider the possible radionuclide scaling factors for atmospheric discharges characterization;

- to identify possible airborne discharges to atmosphere, which are out of control at the NPP with VVER nuclear reactors;

- to determine the list of radionuclides responsible for $99 \%$ of the effective dose for the population from different kinds of Russian reactors.

Experimental data on radionuclide concentrations have been determined in airborne discharges of NPP with different kind of reactors:

- Kursk NPP with light water graphite reactor RBMK-1000;

- Balakovo NPP with VVER-10oo;

- Beloyarskaya NPP with fast breeder reactor BN-80o.

Some dose-forming radionuclides, which were not possible to be determined by a standard radiation 
monitoring system, have been measured by a special measuring system with a low detection level. The measurements were carried out between July and September 2016 under the standard operating conditions of the nuclear power plant.

\section{MATERIALS AND METHODS}

Analysis included comparison of atmospheric discharges of radionuclides for Russian and European NPP. The values of specific indicators of annual atmospheric discharges of radionuclides for Russian NPP are given per unit of produced electricity $(\mathrm{GW} \cdot \mathrm{h})$ during the observation period from 2006 to 2015 [5]. Comparative analysis of Russian NPP discharges to Europe NPP was carried out. Source data is based on the official information of European Commission on nuclear radioactive discharges in Europe between 1995 and 2014 [6]. Data on NPP produced electricity is represented at the IAEA website [7]. In various European countries with PWR nuclear reactors from 1 to 53 radionuclides are under control, and the total amount of controlled radionuclides is up to 83 (Figure 1).

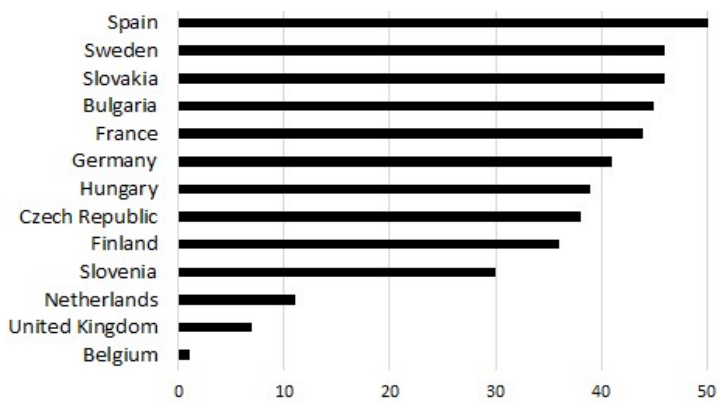

Figure 1. Number of controlled radionuclides in discharges (Europe)

Atmospheric discharges of 7 radionuclides including Cs 134,137, Co-58,60, Cr-51, Mn-54, I-131 as well as total $\beta$-activity and total activity of noble gases are under control in Russia. Measurements of $\mathrm{H}-3$ and C 14 are conducted at specific sources within the frame of monitoring program.

Analysis of discharges of radionuclides was performed to examine the possible correlations for three groups of PWR NPP:

- 8 NPP in Germany (13 NPP units);

- 20 NPP in France (58 NPP units);

- 7 NPP of the Russian/Soviet design in Europe (18 NPP units: Bulgaria - 2, Czech Republic - 6, Finland - 2, Hungary - 4, Slovakia - 4).

The analysis of specific indicators of discharges (Bq per $\mathrm{GW} \cdot \mathrm{h}$ of produced electricity) includes:

- definition of type and parameters of distribution of discharges for the 3 groups of PWR NPP in Europe;

- assessment of significance of differences in specific parameters of discharges;

- calculation of pair correlations of specific indicators;
- creation of associations for each radionuclide controlled at NPP of Russia by value of correlation coefficient more than 0.75 in each of groups;

- evaluation of discharges of $\mathrm{H}-3$ and C-14 at Russian VVER NPP, which are out of routine control.

The standard system of the Russian NPP radiation monitoring of aerosol has the airflow through the analytical filters from 20 to $70 \mathrm{dm}^{3} / \mathrm{min}$, depending on the NPP. The daily amount of air pumped through the filter is in the range from 30 to $100 \mathrm{~m}^{3}$. In this investigation, in which highly efficient sampling equipment was used, the daily air volume for aerosol sampling was from $3500 \mathrm{~m}^{3}$ to $12500 \mathrm{~m}^{3}$. This approach allows decreasing the minimal detection level of radioactive aerosol concentration by 2-3 orders.

To measure the concentration of noble gases in nuclear power plant discharges, the hermetically sealed Marinelli vessel with the overpressure of up to $500 \mathrm{kPa}$ was used. The activity measurements of aerosol filters and Marinelli vessel were conducted on HPGe detector. Activity of $\mathrm{Sr}-90$ was measured by radiochemistry method. The special sampling equipment for HTO, HT and $\mathrm{C}-14$ was used in this investigation. HTO was sampled by bubbling a portion of air through a vessel with distilled water. After additional thermal oxidation, HT also was absorbed in distilled water as HTO. Radiocarbon in the form of $\mathrm{CO}_{2}$ was absorbed in $\mathrm{NaOH}$ solution. Activity of $\mathrm{H}-3$ and $\mathrm{C}-14$ was measured by liquid scintillation spectrometer.

\section{RESULTS \\ 3.1. Analysis of atmospheric discharges of radionuclides in Europe}

Contribution of activity of selected radionuclides to total activity has both similarities and differences to each group of NPP. Common characteristic of the discharges is the predominance of noble gases in the total activity (Figure 2).

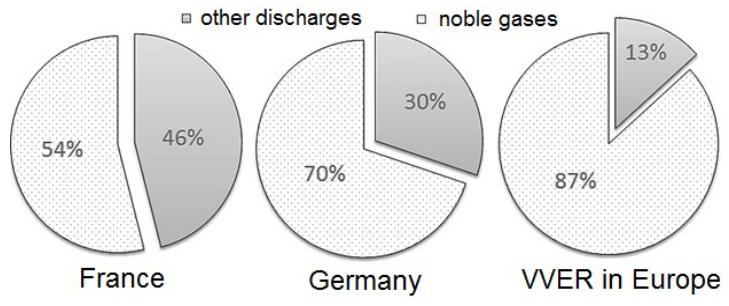

Figure 2. The contribution of noble gases in the total normalized discharge activity

Another common characteristic is the fact, that activity of radionuclides except noble gases is formed by two radionuclides ( $\mathrm{H}-3$ and $\mathrm{C}-14$ ) for $99.9 \%$ (Figure 3). On the other hand, noble gases radionuclides structure in discharges is specific to each of the groups (Figure 4).

Average values of specific radionuclides discharges $(\mathrm{Bq} / \mathrm{GW} \cdot \mathrm{h})$ with Russian design of nuclear reactor in Europe are significantly higher than those for PWR 
NPP for all radionuclides which are under control in Russia.

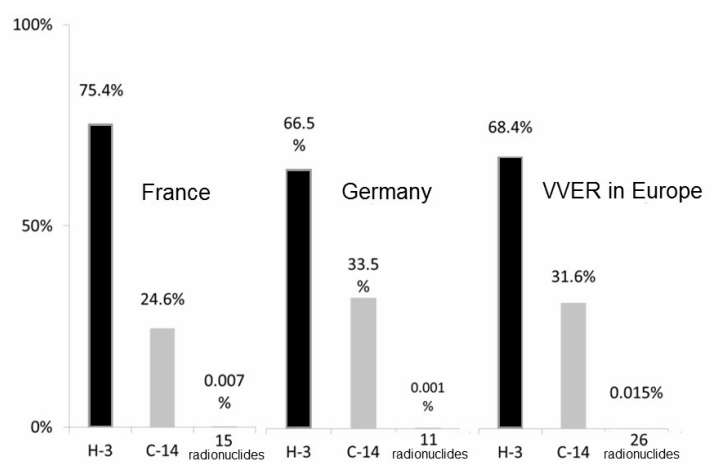

Figure 3. Radionuclides except noble gases structure in discharges of NPP
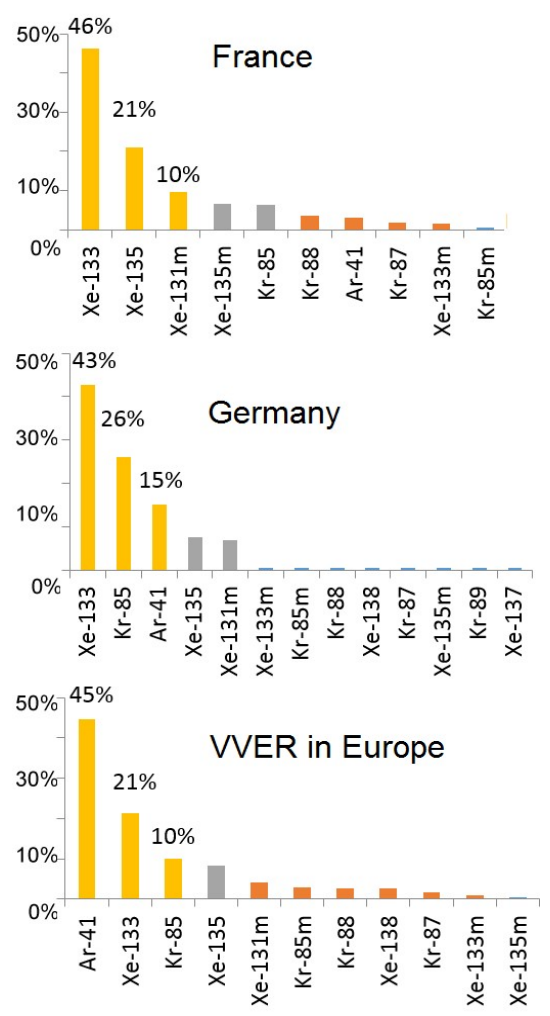

Figure 4. Noble gases radionuclides structure in discharges of NPP

Figure 5 shows an example of average values of specific parameters for $\mathrm{H}-3, \mathrm{C}-14, \mathrm{Co}-60$ with $95 \%$ confidence intervals. The number of measurements was sufficient to assess the statistical significance of differences between the specific indicators of NPP for different nuclear reactors with $\alpha=0.05$ for Cs-134,137, Co-58,60, Cr-51, Mn-54, I-131, H -3 and C-14.

Comparison of specific indicators of atmospheric radionuclide discharges for NPP of different groups indicates that European NPP with Russian/Soviet design has the greatest potential to reduce the impact of activity emission.
Associations with each radionuclide controlled at NPP in Russia can be formed with correlation coefficient more than 0.75 in each group. The list of associated radionuclides for different groups is shown in Table 1.
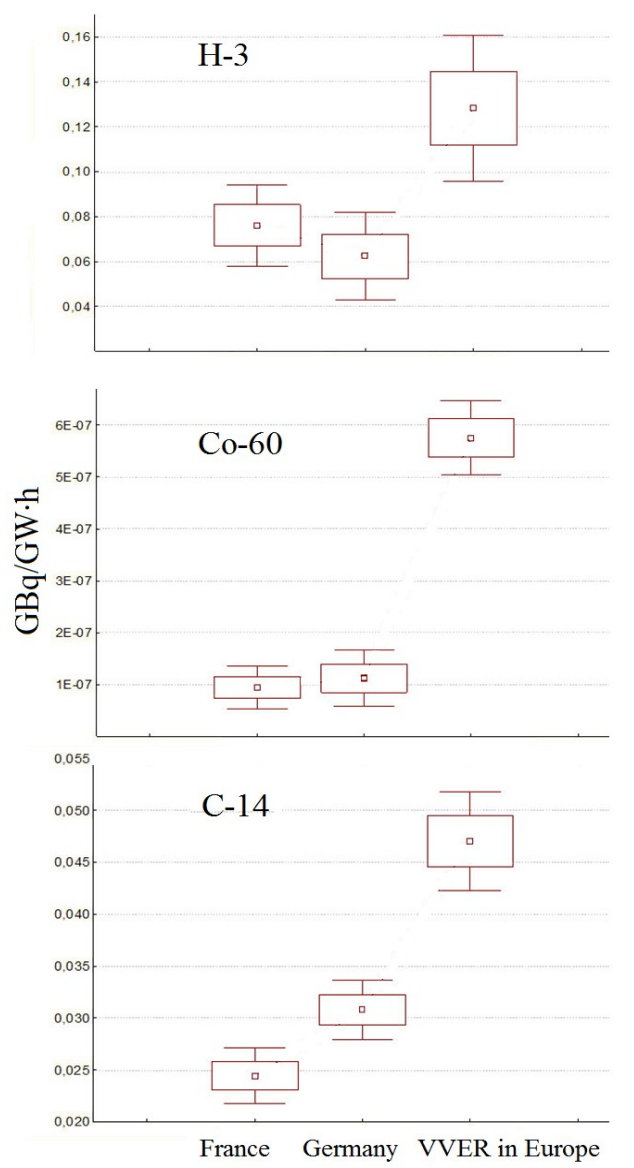

Figure 5. Comparison of specific indicators of NPP with different nuclear reactors

Table 1. Associated radionuclides (correlation coef. > 0.75)

\begin{tabular}{|c|c|c|c|}
\hline \multirow{2}{*}{$\begin{array}{l}\text { Key } \\
\text { radionu } \\
\text { clide } \\
\end{array}$} & \multicolumn{3}{|c|}{ Associated radionuclides } \\
\hline & France (PWR) & $\begin{array}{c}\text { Germany } \\
\text { (PWR) }\end{array}$ & Other (VVER) \\
\hline $\mathrm{Cr}-51$ & $\mathrm{Xe}-135 \mathrm{~m}$ & $\mathrm{Xe}-137$ & $\begin{array}{l}\text { Mn-54, Co-58, Co-6o, } \\
\text { Kr-85, Kr-85m, Kr-87, } \\
\text { Zr-95, Nb-95, Sb-124 }\end{array}$ \\
\hline Mn-54 & Ag-110m & - & $\begin{array}{l}\text { Cr-51, Co-58, Co-60, } \\
\text { Zr-95, Nb-95, Kr-85, } \\
\text { Kr-85m, Kr-87, Sb- } \\
\text { 124, Xe-133 }\end{array}$ \\
\hline Co-58 & Co-6o & - & $\begin{array}{c}\mathrm{Cr}-51, \mathrm{Mn}-54, \mathrm{Co}-60 \\
\mathrm{Kr}-85, \mathrm{Kr}-85 \mathrm{~m}, \mathrm{Kr}-87, \\
\mathrm{Zr}-95, \mathrm{Nb}-95, \mathrm{Sb}-124\end{array}$ \\
\hline Co-6o & $\begin{array}{l}\text { Co-58, Cs-134, } \\
\text { Cs-137, Kr-85, } \\
\text { Sb-124, Xe-133 }\end{array}$ & Te-123m & $\begin{array}{c}\mathrm{Cr}-51, \mathrm{Mn}-54, \mathrm{Co}-58 \\
\mathrm{Kr}-85, \mathrm{Kr}-85 \mathrm{~m}, \mathrm{Nb}-95 \\
\text { Sb-124 }\end{array}$ \\
\hline $\mathrm{I}-131$ & - & $\begin{array}{c}\mathrm{Kr}-85 \mathrm{~m}, \\
\mathrm{Xe}-133 \mathrm{~m}, \\
\mathrm{Xe}-135\end{array}$ & \begin{tabular}{|c|}
$\mathrm{I}-133, \mathrm{Kr}-85, \mathrm{Kr}-85 \mathrm{~m}$ \\
$\mathrm{Kr}-87, \mathrm{Zr}-95, \mathrm{Sb}-122$ \\
$\mathrm{Xe}-133, \mathrm{Xe}-135$ \\
\end{tabular} \\
\hline Cs-134 & $\begin{array}{l}\text { Co-6o, Cs-137, } \\
\mathrm{Kr}-85, \mathrm{Xe}-133\end{array}$ & - & - \\
\hline Cs-137 & $\begin{array}{l}\text { Co-6o, Cs-134, } \\
\text { Kr-85, Xe-133 }\end{array}$ & - & - \\
\hline
\end{tabular}


It can be assumed that the identified radionuclides scaling factors for European NPP built after designs of the USSR (VVER) are typical for VVER nuclear power operated in Russia. However, the practical confirmation of this assumption is required. Radionuclides $\mathrm{H}-3$ and $\mathrm{C}-14$ do not form associations and cannot be evaluated by the activity of other radionuclides and should be controlled individually.

3.2. Comparison of specific indicators of I-131

discharges of Russian NPP to Europe NPP

discharges

Specific indicators of I-131 for European and Russian NPP with PWR and VVER nuclear reactors for the same period were compared: 13 NPP units in Germany, 58 NPP units in France, 18 European VVER NPP units, 17 Russian VVER NPP units. Belgian PWR NPP are not included in the analysis, because the lack of data on I-131 discharges.

Medians of activity of I-131 discharges are shown in Figure 6 (only values greater than minimum detectable activity are considered). Median of activity of I-131 discharges per unit of produced electricity $(\mathrm{GW} \cdot \mathrm{h})$ for Balakovo NPP is noticeably less than the same for European VVER NPP, and significantly less than the same parameter for NPP of Slovenia, Spain, Sweden, Netherlands and UK.

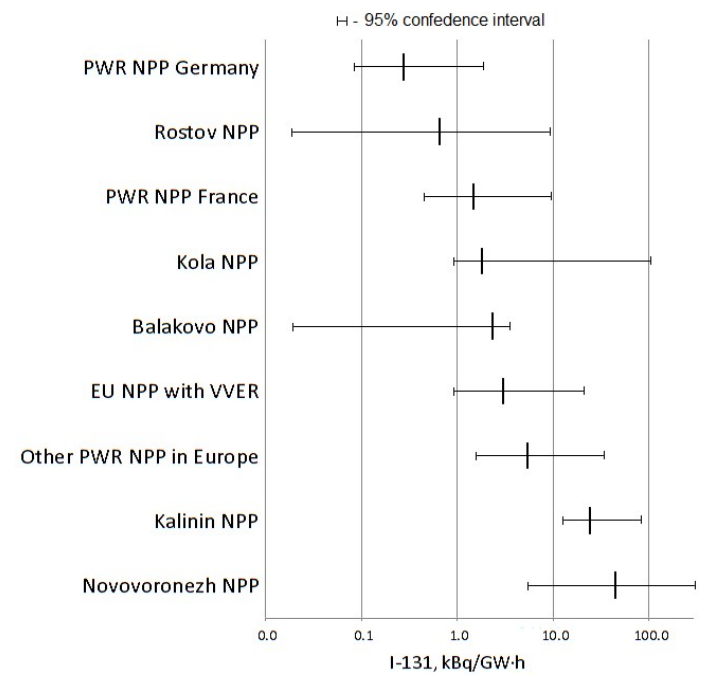

Figure 6. Comparison of specific indicators of Russian NPP discharges to actual Europe NPP discharges of I-131 (logarithmic scale)

It should be noted that PWR NPP in Germany discharged substantially less I 131 in atmosphere per unit of produced electricity (0.3 kBq / GW h). Specific discharges of I-131 in Balakovo and Kola NPP is comparable to France's NPP $(1.5 \mathrm{kBq} / \mathrm{GW} \cdot \mathrm{h})$ and significantly lower than the Europe's NPP with Soviet nuclear reactor design (VVER) discharges $(3.5 \mathrm{kBq} /$ GW - h). In turn, the specific discharges of I-131 for Kalinin NPP are more than 4 times larger than those for European NPP.
3.3. Assessment of $\mathrm{H}-3$ and $\mathrm{C}-14$ discharges to atmosphere, which are out of control at the NPP with VVER nuclear reactors in Russia

Average annual discharges of $\mathrm{H}-3$ and $\mathrm{C}-14$ to atmosphere for Russian VVER NPP were obtained on the basis of the electricity production data (for the period from 2006 to 2015) (Fig. 7).

The initial data for such evaluations are the results of the analysis of specific indicators, normalized to the electricity produced [7]. This evaluation indicates directly proportional relation between tritium discharges and generated electricity. The technical and technological features of each NPP make a significant impact on airborne discharge.

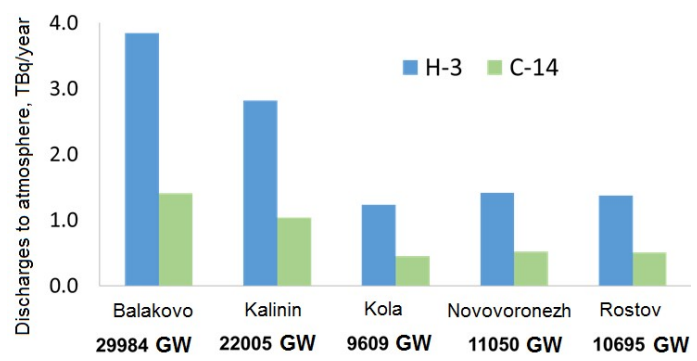

Figure 7. Assessment of $\mathrm{H}-3$ and $\mathrm{C}-14$ discharges to atmosphere at Russian NPP

3.4. Assessment of the list of radionuclides responsible for $99 \%$ of the effective dose for the population from different kinds of Russian reactors

Average values of the total concentration of airborne discharges are:

- $\quad$ Kursk NPP - 2.5.104 Bq/m3;

- Balakovo NPP - 4.4.103 $\mathrm{Bq} / \mathrm{m}^{3}$;

- Beloyarskaya NPP - $30.3 \mathrm{~Bq} / \mathrm{m}^{3}$.

The total annual releases of radionuclides were estimated on the base of their concentration in the air of the ventilation system of the NPP and the air flow in ventilation stack. Effective doses were assessed not on the base of measurements performed at the location of the population, but by calculations based on radionuclide releases from the vent stack. For assessment of the population effective doses CAP-88 4.0 software was applied [8]. The assessment of the effective dose from airborne discharges to critical groups of population for these NPPs gives the values:

- $\quad$ Kursk NPP - 3.8 $10^{-8}$ Sv/year;

- Balakovo NPP - 9.3.10 $10^{-8} \mathrm{~Sv} /$ year;

- Beloyarskaya NPP $-3.1 \cdot 10^{-10} \mathrm{~Sv} /$ year.

33 radionuclides were detected in Kursk NPP airborne discharges, but only 13 create $99 \%$ of the effective dose to population, Figure 8.

In this case, the standard radiation monitoring system of Kursk NPP does not allow controlling radionuclides which are responsible for $95 \%$ of the effective dose to population. 

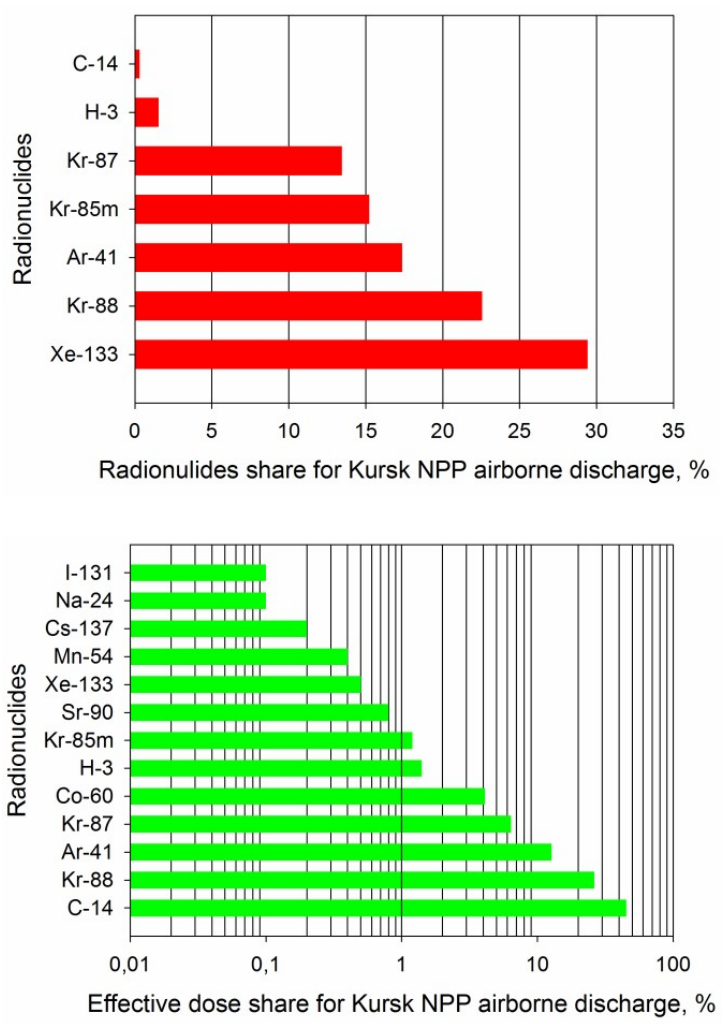

Figure 8. Results from Kursk NPP airborne discharge

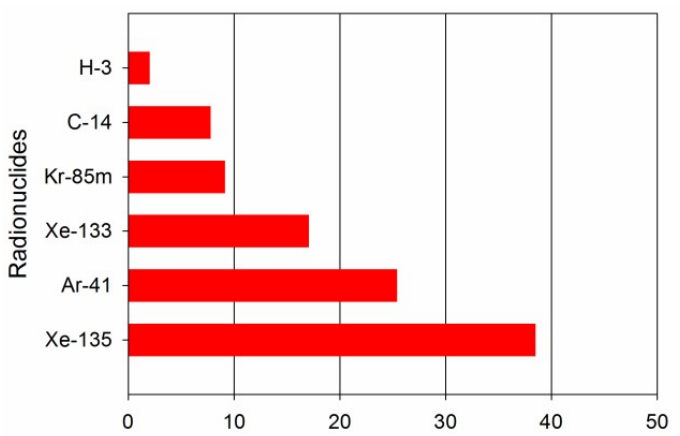

Radionulides share for Balokovo NPP airborne discharge, \%

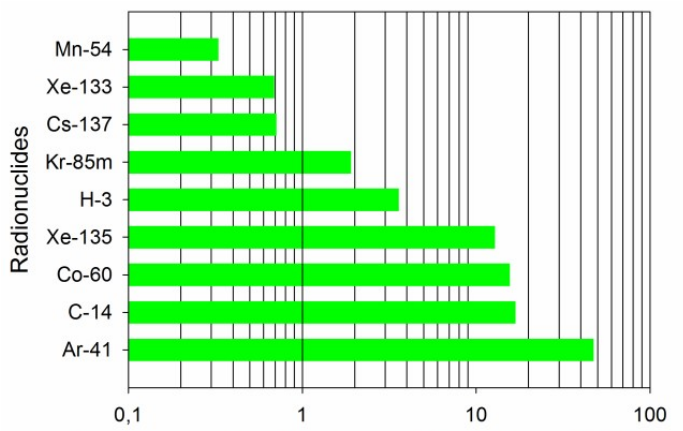

Effective dose share for Balokovo NPP airborne discharge, \%

Figure 9. Results from Balakovo NPP airborne discharge
In Balakovo NPP, airborne discharges of 11 radionuclides were detected, but only 9 create $99 \%$ effective dose to population, Figure 9.

In this case, the standard radiation monitoring system of Balakovo NPP does not allow controlling radionuclides, which are responsible for $84 \%$ of the effective dose to the population.

Only 3 radionuclides were detected in Beloyarskaya NPP airborne discharges:

$\mathrm{H}-3-27.5 \mathrm{~Bq} / \mathrm{m}^{3}$;

$\mathrm{Bi}-214$ - 2.7 Bq $/ \mathrm{m}^{3}$;

$\mathrm{Pb}-212-0.04 \mathrm{~Bq} / \mathrm{m}^{3}$.

In this case, tritium is the main dose-forming radionuclide for a new reactor $\mathrm{BN}-800$.

The obtained experimental data on airborne discharge radionuclide composition from NPPs with different reactors have a good correlation with the European data [1].

The information about the exposure of the critical group of population allows the creation of the list of 15 radionuclides which are responsible for $99 \%$ of the effective dose to population and are recommended for control at Russian NPPs, Table 2. This list of radionuclides corresponds to the list recommended by IAEA for the assessment of the exposure on population and environment during the NPP operation [3].

The list of radionuclides presented in Table 2 should be considered as a preliminary list because it was formed on the base of the measurements conducted on the limited number of NPPs and in limited periods.

Table 2. List of radionuclides responsible for $99 \%$ of effective dose and recommended for control at Russian NPPs

\begin{tabular}{|l|l|l|l|l|l|}
\hline$\#$ & $\begin{array}{c}\text { Radio } \\
\text { nuclide }\end{array}$ & $\#$ & $\begin{array}{c}\text { Radio } \\
\text { nuclide }\end{array}$ & $\#$ & $\begin{array}{c}\text { Radio } \\
\text { nuclide }\end{array}$ \\
\hline 1 & $\mathrm{Ar}-41$ & 6 & $\mathrm{Xe}-135$ & 11 & $\mathrm{Mn}-54$ \\
\hline 2 & $\mathrm{Kr}-85 \mathrm{~m}$ & 7 & $\mathrm{H}-3$ & 12 & $\mathrm{Cs}-137$ \\
\hline 3 & $\mathrm{Kr}-87$ & 8 & $\mathrm{C}-14$ & 13 & $\mathrm{Na}-24$ \\
\hline 4 & $\mathrm{Kr}-88$ & 9 & $\mathrm{Co}-60$ & 14 & $\mathrm{I}-131$ \\
\hline 5 & $\mathrm{Xe}-133$ & 10 & $\mathrm{Sr}-90$ & 15 & $\mathrm{Cs}-134$ \\
\hline
\end{tabular}

\section{CONCLUSION}

1. Dynamics of discharges to atmosphere is specific to each selected group of NPP during the chosen period.

2. Comparison of specific indicators of atmospheric radionuclide discharges for NPP of different groups indicates that European NPP with Russian/Soviet design has the larger activity emission per unit of produced electricity. 
3. For each radionuclide controlled at NPP in Russia there may be formed associations with other radionuclides.

4. Activity of airborne discharges is formed by noble gases and two radionuclides $(\mathrm{H}-3$ and $\mathrm{C}-14)$ for 99.9\%. Radionuclides $\mathrm{H}-3$ and $\mathrm{C}-14$ do not form associations and can not be evaluated by the activity of other radionuclides and should be controlled individually.

5. Up to 33 radionuclides were identified in a regular airborne discharge of Kursk, Balakovo and Beloyarskaya NPPs. Only 15 of all measured radionuclides are responsible for at least $99 \%$ of the effective dose to the critical group of population.

6. Results of this investigation demonstrate that the NPP with a fast breeder reactor has a distinct advantage in the amount of activities and radioactive substance composition released into the atmosphere in comparison with NPPs with other types of reactors. The regular airborne discharges from NPPs with a reactor on fast neutrons create the lowest value of the effective dose to the critical group of population.

Acknowledgement: This work supported by project 15-2-19 of Ural Branch of Russian Academy of Science

\section{REFERENCES}

1. A. A. Ekidin, M. V. Zhukovskii, M. E. Vasyanovich, "Identification of the Main Dose-Forming Radionuclides in NPP emissions," Atomic Energy, vol. 120, no. 2, pp. 134-137, May. 2016. DOI: $10.1007 / \mathrm{s} 10512-016-0107-\mathrm{x}$

2. S. I. Spiridonov, E. I. Karpenko, and L. A. Sharpan, "Ranking of radionuclides and pathways according to their contribution to the dose burden to the population resulting from NPP releases," Rad. Biol. Radioecol., vol. 53, no. 4 pp. 401-410, Aug. 2013. PMid:25427373

3. INPRO Methodology for Sustainability Assessment of Nuclear Energy Systems: Environmental Impact of
Stressors, International Atomic Energy Agency, Vienna, Austria, 2016.

Retrieved from:

http://www-

pub.iaea.org/MTCD/Publications/PDF/Pub1733 web. pdf

Retrieved on: Feb. 11, 2017

4. Правительство Российской Федерации. (июль 8 , 2015). N 1316-р Перечнь загрязняющих веществ, в отношении которых применяются меры государственного регулирования в области охраны окружающей среды.

(Government of the Russian Federation. (Jul. 8, 2015)

$N$ 1316-p List of pollutants, which are subject to state regulation measures in the field of environmental protection.)

Retrieved from:

https://rg.ru/2015/07/13/pollutanty-site-dok.html

Retrieved on: Feb. 11, 2017

5. Радиационная обстановка на территории России и сопредельных государств в 2006 - 2015 годах, Научно-производственное объединение «Тайфун», Обнинск, Россия,2007-2016 (Radiation conditions on the territory of Russia and adjoining states in 20062015, Scientific and Industrial Association Taifun, Obninsk, Russia (2007-2015)).

Retrieved from:

http://www.rpatyphoon.ru/products/pollutionmedia.php

Retrieved on: Feb. 11, 2017

6. Radioactive Discharges Database, European

Commission, Brussels, Belgium, 2016.

Retrieved from:

http://europa.eu/radd/nuclideDischargeOverview.dox? pageID=NuclideDischargeOverview Retrieved on: Feb. 5, 2016

7. The Database on Nuclear Power Reactors, International Atomic Energy Agency, Vienna, Austria, 2016.

Retrieved from: https://www.iaea.org/PRIS/

Retrieved on: Apr. 10, 2016

8. Trinity Engineering Associates, Cincinnati (OH), USA, 2014, CAP88-PC Version 4.o.

Retrieved from:

https://www.epa.gov/radiation/cap-88-cap-88-pc\#tab$\underline{2}$

Retrieved on: Feb. 11, 2017 